\title{
Educação no/do Campo como resistência e enfrentamento das desigualdades
}

\author{
Education in/of the Countryside as resistance and facing of the \\ inequalities
}

\section{Educación en el/del Campo como resistencia y enfrentamiento de las desigualdades}

\author{
Raimunda Áurea Dias de Sousa \\ https:/ / orcid.org/0000-0002-4646-4500 \\ aurea.souza@upe.br \\ Universidade de Pernambuco, UPE, Petrolina, PE \\ Maria Arlandia Reis Silva \\ https:// orcid.org/0000-0001-8334-229X \\ arlandiareis@hotmail.com \\ Universidade de Pernambuco, UPE, Petrolina, PE
}

Resumo: $\mathrm{O}$ entendimento de que a conquista da educação é tão importante quanto à ocupação de um latifúndiofaz parte de uma construção contínua dentro dos movimentos sociais do campo, particularmente, no MST (Movimento dos Trabalhadores Rurais Sem Terra). Assim, este artigo pretende analisar a Educação no/do Campo enquanto uma política pública no enfrentamento das desigualdades historicamente acirradas pela divisão cidade-campo, ao tempo que resiste ao modelo educacional imposto pela burguesia agrária. Os resultados apontam que as políticas educacionais só têm sentido quando pensada com os sujeitos, e não para os sujeitos - sobretudo os do campo, que historicamente foram excluídos do direito à uma educação que não fosse meramente presencial. Nesse sentido a Educação do Campo é importante no desenvolver de um papel na disputa de hegemonia de projetos de campo, de sociedade e de formação humana.

Palavras-chave: Educação, território, assentamento, camponeses, trabalho.

Abstract: The understanding that the achievement of education is as important as the occupation of a latifundio is part of a continuous construction within the social movements of the countryside, particularly, in the MST (Landless Rural Workers Movement). Thus, this paper aims to analyze Education in/of Country as a public policy in coping with the inequalities historically fierce by the city-countryside division, while resisting the educational model imposed by the agrarian bourgeoisie. The results indicate that educational policies only have meaning when thought with the subjects, and not for the subjects - especially those in the countryside, who have historically 
been excluded from the right to an education that was not merely presential. In this sense, Countryside Education takes an important role in the dispute of hegemony of country design, society, and human formation.

Keywords: Education, territory, settlement, peasants, work.

Resumen: El entendimiento de que la conquista de la educación es tan importante como la ocupación de un terrateniente es parte de una construcción continua dentro de los movimientos sociales del campo, particularmente en el MST (Movimiento de Trabajadores Rurales Sin Tierra). Por lo tanto, este artículo pretende analizar la Educación en / el Campo como una política pública para hacer frente a las desigualdades históricamente afectadas por la división ciudad-campo, al tiempo que se resiste al modelo educativo impuesto por la burguesía agraria. Los resultados indican que las políticas educativas sólo tienen sentido cuando se piensa con los temas, y no para los sujetos, especialmente aquellos en el campo, que históricamente han sido excluidos del derecho a una educación no simplemente cara a cara. En este sentido, la educación de campo es importante para desarrollar un papel en la disputa de la hegemonía de los proyectos de campo, de sociedad y de formación humana.

Palabras clave: Educación, territorio, asentamiento, campesinos, trabajo.

\section{INTRODUÇÃO}

A Educação do Campo nasce por uma necessidade de associar terra, trabalho e a cultura do campo e, por essa razão é incompatível com o modelo de agricultura capitalista conhecida na atualidade como agronegócio ${ }^{1}$, justamente porque tal modelo exclui os camponeses de fazer do campo uma opção de vida com dignidade. Assim, a Educação do campo se contrapõem a rural porque não tem por base o mercado, ao contrário, fortalece um modelo popular de agricultura, identificando as características da produção camponesa que devem ser preservadas, e também as que devem ser transformadas na perspectiva de um projeto de desenvolvimento comum.

Enquanto perspectiva educacional, a Educação do Campo, possui um forte vínculo com os territórios dos sujeitos do campo e suas territorialidades específicas, ancorada na agricultura camponesa, na agroecologia, no campo como espaço de vida, cultura e trabalho etc., e se apresenta, como uma política capaz de contribuir no combate às desigualdades educacionais existentes em nosso país.

Desse modo, a pesquisa realizada foi norteada pelo seguinte problema: Como a Educação no/ do $^{2}$ Campo se constitui como uma política pública no enfrentamento das desigualdades historicamente acirradas pela divisão cidade-campo, ao tempo que resiste ao modelo educacional imposto pela burguesia agrária? A necessidade de discutir a problemática proposta e alcançar o objetivo desejado conduziu a uma reflexão crítica do

1 O agronegócio na acepção brasileira do termo é uma associação do grande capital agroindustrial com a grande propriedade fundiária. Essa associação realiza uma estratégica econômica de capital financeiro, perseguindo o lucro e a renda da terra, sob patrocínio de políticas de Estado (Delgado, 2005).

2 Para Caldart (2012, p.18) “No: o povo tem direito de ser educado no lugar onde vive; Do; o povo tem direito a uma educação pensada desde seu lugar e com sua participação vinculada à sua cultura e às suas necessidades humanas e sociais". 
modelo agrícola implantado no Vale do São Francisco e em Petrolina (PE) nos últimos anos. Desse modo, a dimensão histórica dialética é a garantia da leitura processual da dinâmica dos movimentos internos inscritos na totalidade das relações sociais mundiais.

Dentro dessa perspectiva, o presente artigo tem como ponto de partida o estudo realizada em duas escolas municipais localizadas em assentamentos da Reforma Agrária: a escola Senador Mansueto de Lavor da FETAPE (Federação dos Trabalhadores Rurais Agricultores e Agricultoras do Estado de Pernambuco) e a Maria da Graça de Souza no São Francisco do MST; ambas estão situadas, na zona rural do Distrito de Izacolândia, aproximadamente a $60 \mathrm{~km}$ da sede do Município de Petrolina, no Sertão Pernambucano. Os assentamentos e suas escolas foram escolhidos pelo desafio de entender como terra e educação devem fazer parte de uma mesma bandeira na luta por Reforma Agrária e no enfrentamento das desigualdades.

Assim, os caminhos percorridos centram-se nos seguintes eixos de operacionalização: a) apresentação dos pressupostos da pesquisa baseada em autores como Oliveira (2001), Harvey (2004), Fernandes e Stédile (2005), Shanin (2008), Mészáros (2008), Molina e Rocha (2014), Fabrini e Roos (2014) e Ribeiro (2015), dentre outros, por considerar que esses permitem apreender a problemática sem descartar a historicidade; b) resultados da pesquisa de campo qualitativa/quantitativa com os sujeitos da práxis pedagógica - professores, estudantes e dirigentes do movimento; c) análise documental concernentes à criação das escolas e as relações com a comunidade. Para tal, estabeleceu-se um recorte temporal a partir do início da construção das escolas em 1999, por entender que, nesse momento, terra, educação e trabalho passariam a caminhar juntos na concretização da Reforma Agrária.

\section{EDUCAÇÃO NO/DO CAMPO - UM TERRITÓRIO EM DISPUTA}

A educação do campo materializa a luta política dos trabalhadores camponeses contra todas as formas de exploração do capitalismo, principalmente com relação ao enfrentamento de modelos agrícolas diferenciados: agricultura camponesa (território da existência humana) versus o agronegócio (setor da economia, do lucro). Portanto, há disputa do território, já que para os camponeses a terra é a garantia da vida, ao passo que para o agronegócio a terra é, verdadeiramente, um negócio.

Nesse sentido, D'Agostini (2012) destaca que o campo é espaço de disputa de projetos políticos e de desenvolvimento do país, tendo como concepção de desenvolvimento hegemônico do agronegócio e, na contrapartida, a ação de movimentos de lutas sociais que reivindicam a reforma agrária. Partindo dessa afirmação, pode-se analisar o movimento dessa disputa, no caso do Sertão Pernambucano, em Petrolina (PE), a área ocupada com assentamentos de Reforma Agrária corresponde a 23.347,9627 ha com capacidade para 1.082 famílias. Dessas, apenas 141 foram tituladas enquanto 905 ainda não adquiriram seus títulos de posse.

Conforme a Tabela 1, pode-se observar que as disputas não se resumem somente à questão de terra, e nem a Reforma Agrária é entendida nessa perspectiva. São diversas 
lutas que se iniciam em ocupações, acampamento ${ }^{3}$, assentamento, titulação das terras, condições de moradia, de plantio, de escola, ou seja, de trabalho, de condição de vida. Ao passo que se conquista a terra, é necessário que constitua território, e para isso o ponto de partida é a titulação das áreas para que as famílias possam, inclusive, deixar para seus descendentes. A dificuldade para titulação nos assentamentos mencionados e nos demais em Petrolina ${ }^{4}$, encontra-se na expansão do agronegócio voltado para produção de fruticultura destinado ao mercado externo.

Consequentemente, o retardo na titulação das famílias implica não ter acesso às políticas de reforma agrária, dentre elas a Educação do Campo, o que resulta em assalariamento e precarização do trabalho nas grandes empresas que se dedicam a produzir para o mercado externo.

Tabela 1: Famílias tituladas e não tituladas nos assentamentos Senador Mansueto de Lavor, da FETAPE, e São Francisco, do MST, em Petrolina, PE.

\begin{tabular}{l|c|c|c}
\hline ASSENTAMENTOS & CAPACIDADE DE FAMÍLIAS & TITULADAS & NÃO TITULADAS \\
\hline $\begin{array}{l}\text { Senador Mansueto de } \\
\text { Lavor da FETAPE }\end{array}$ & 100 & 46 & 54 \\
\hline São Francisco do MST & 60 & 39 & 19 \\
\hline
\end{tabular}

Fonte: INCRA (2018).

Relativo ao assunto, Fernandes e Molina (2008) destacam que há territórios diferentes: o campo do agronegócio (Educação Rural) e o campo da agricultura familiar camponesa (Educação no/do Campo). Essa realidade é evidenciada, por exemplo, nos investimentos do Estado brasileiro, nas políticas de financiamento para o desenvolvimento do agronegócio (Fig. 1).

3 Acampamento é um espaço de luta e resistência. É a materialização de uma ação coletiva que torna pública a intencionalidade de reivindicar o direito à terra para produção e moradia. O acampamento é uma manifestação permanente para pressionar os governos na realização da Reforma Agrária (Fernandes, 2013, p. 21).

4 De acordo com o Censo Agropecuário 2017/2018 do total da área irrigada em Pernambuco 192.806ha, somente Petrolina abarca 39.730ha, que corresponde 20,6\% de todo estado. Em relação aos estabelecimento com uso de irrigação - Pernambuco 39.586ha e Petrolina 4.220ha. 
Figura 1: Recursos públicos destinados ao agronegócio e à agricultura familiar. Safras 2002/03 a 200/2021- Brasil (Bilhões de R\$)

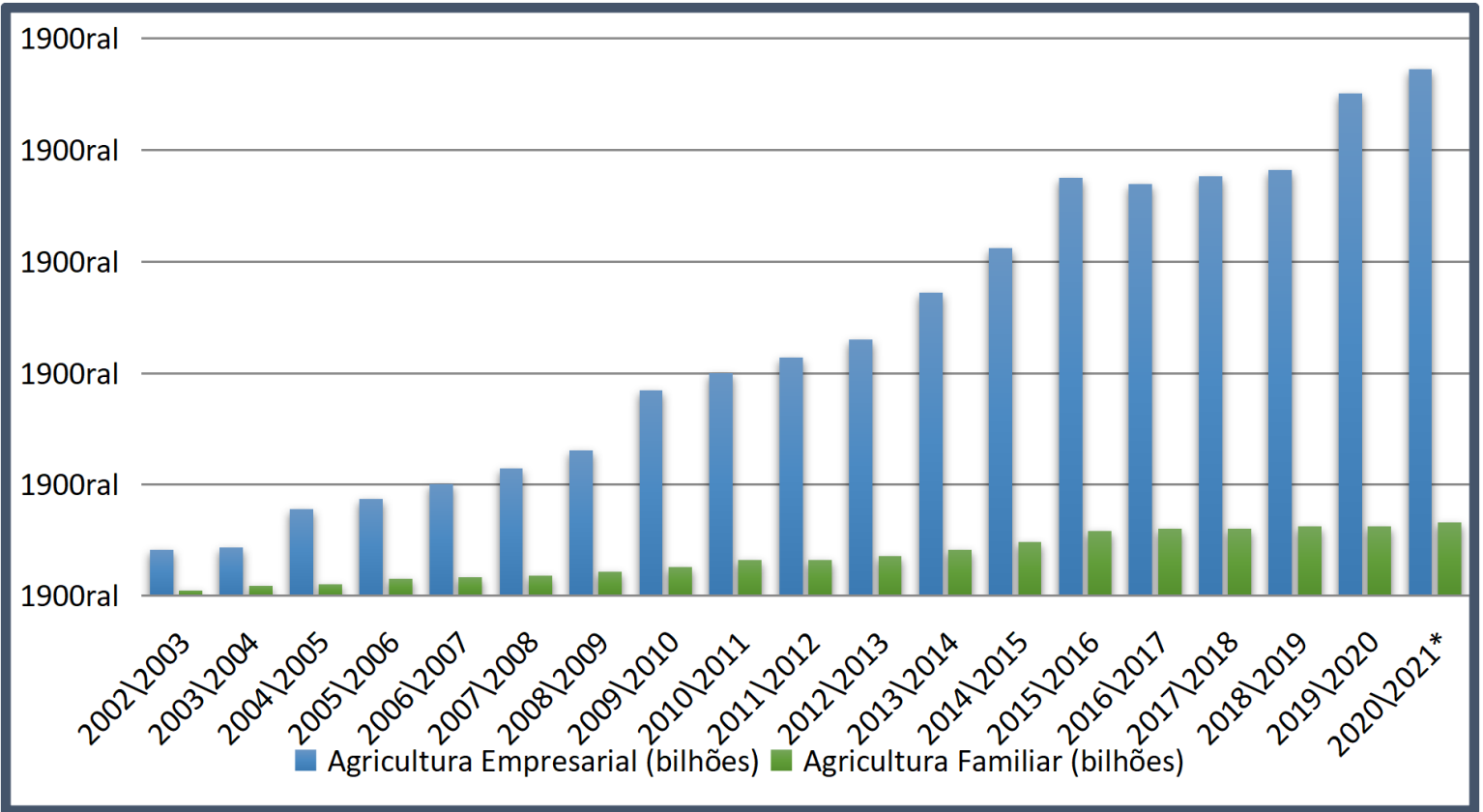

Fonte: elaborado a partir de dados do MAPA (2020), recuperado de https:/ /www.gov.br/agricultura/ptbr/assuntos/politica-agricola/plano-agricola-e-pecuario/arquivos-pap/livropap1617.pdf/view.

Dentro dessa lógica de disputa, encontra-se o processo de construção do território que, para Oliveira (1998), é simultaneamente construção/destruição/manutenção/ transformação. Em meio a disputa consolidam-se os territórios distintos entre Educação Rural pensada como forma de inserção no modelo de desenvolvimento predominante, o agronegócio, enquanto a Educação do/no Campo é pensada de acordo com a realidade dos sujeitos e para eles.

No que se refere à Educação do Campo, Fernandes e Molina (2008, p. 21) argumentam que

A Educação do Campo não existe sem a agricultura camponesa, porque foi criada pelos sujeitos que a executam. Neste sentido, a concepção de campo e de educação deve contemplar o desenvolvimento territorial das famílias que trabalham e vivem da terra. A agricultura camponesa vive em confronto permanente com a agricultura capitalista. E se o agronegócio avança, também avançam os movimentos camponeses na construção de seus territórios. (Grifo nosso).

A agricultura camponesa estabelece, portanto, o confronto constante com o agronegócio devido ao modo de vida próprio do campesinato, com a combinação de elementos da produção, fundamentados na força de trabalho familiar, entre outros elementos que, segundo Oliveira (2007), dão sentido às formas de reprodução social camponesa (Fig. 2). 
Figura 2: Elementos da produção camponesa

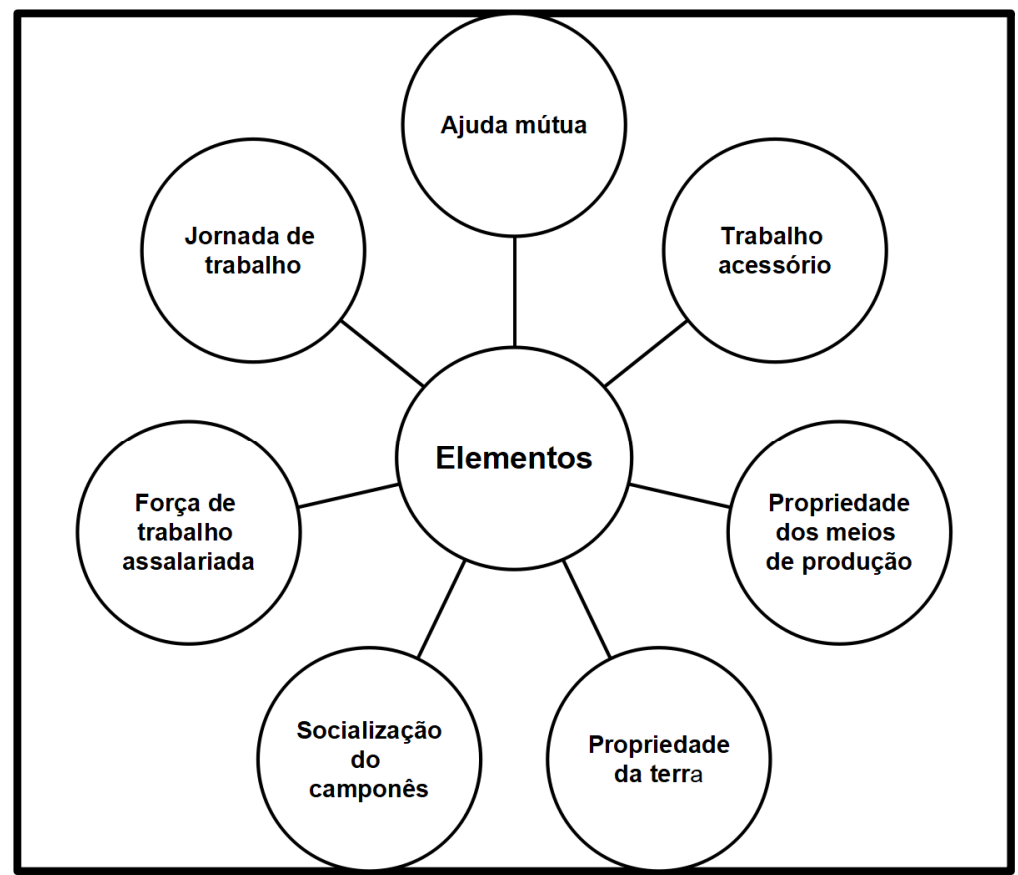

Fonte: elaborado de Oliveira (2007).

Assim, como Oliveira (2007), Shanin (2008), também destaca a força de trabalho familiar como um dos principais elementos da economia camponesa-(Fig. 3).

Figura 3: Presença do trabalho familiar no Assentamento São Francisco, Petrolina, PE.

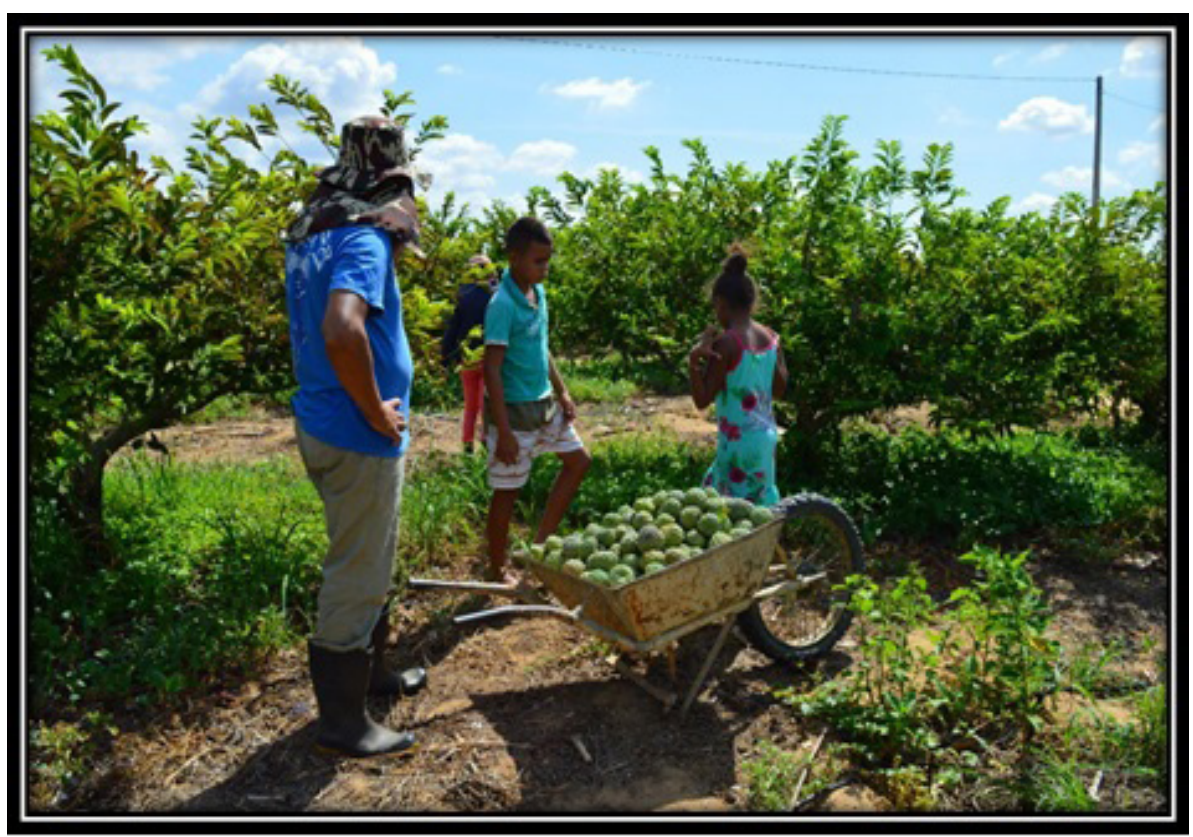

Imagem: acervo M.A.R. Silva, 2018.

No que se refere ao contexto educacional, Fernandes (2006) explica que há dois campos paradigmáticos, que disputam princípios e diretrizes: o Paradigma do Capitalismo 
Agrário (PCA) e o Paradigma da Questão Agrária (PQA). No primeiro campo paradigmático, a questão agrária não existe porque os problemas do desenvolvimento do capitalismo são resolvidos pelo próprio capital. Portanto, as soluções são vistas a partir do mercado, com a lógica de valores de troca, da competitividade e de uma eficiência que extenua o trabalho e aniquila os bens comuns (terra, água, florestas, entre outros). Inserida nesse paradigma, a Educação Rural é pensada de cima para baixo, ou seja, os camponeses não são sujeitos do processo, mas subalternos aos interesses do capital.

No segundo, a questão agrária é inerente ao desenvolvimento desigual e contraditório do capitalismo e, nesse caso, as políticas são demandadas pelos movimentos sociais e trabalhadores como instrumentos de luta contra o capital. Dentro dessa perspectiva, a Educação do Campo entende que desenvolvimento e educação são indissociáveis. Por essa razão, passou a ser construída pelos movimentos camponeses a partir do princípio da autonomia dos territórios (Fig. 4).

Figura 4: Paradigma da Questão Agrária.

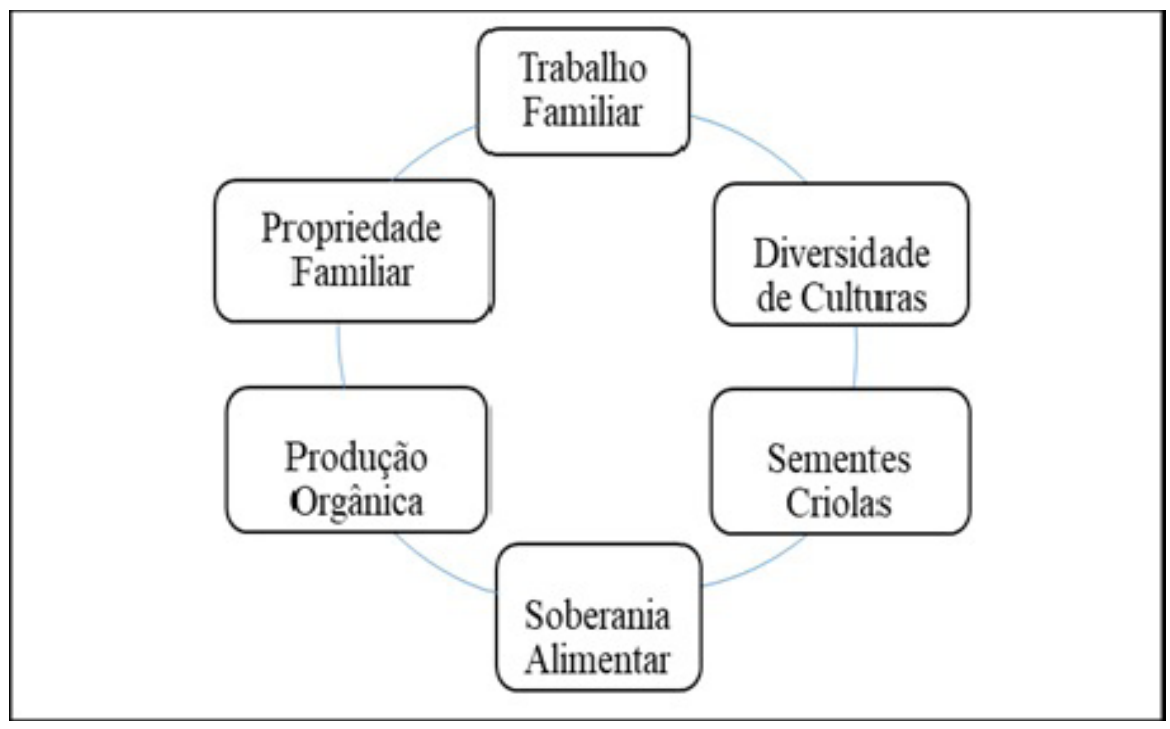

Fonte: elaborado de Fernandes e Molina (2008).

O agronegócio e a agricultura família/camponesa se entrelaçam e se distanciam, e é nesse par dialético que entra a Educação do Campo construída junto aos movimentos sociais do campo, em especial o MST, na luta por terra e nas contradições do próprio avanço do agronegócio. Ela passa a ser um instrumento de resistência contra o referido modelo. Assim, a Educação no Campo reforça e valoriza as formas identitárias e de representação social camponesa, porque reconhece seus saberes e fazeres como instrumentos de resistência social.

A preocupação com a educação surge dentro do movimento junto com o seu processo de organização, nas primeiras ocupações, em 1979, das fazendas Macali e Brilhante (Ronda Alta, RS) e, logo depois, em 1981, no acampamento na Encruzilhada do Natalino, no mesmo Estado. Essas primeiras ocupações foram fundamentais para o movimento, como retrata o trecho da música Só a luta faz valer de Lima (2005). 
Esse evento traz presente um passado

De uma semente que deu vida ao movimento

No broto novo de Macalli e Brilhante

A Encruzilhada Natalino pôs fermento.

Ocupar e acampar foram alternativas que o MST utilizou para pressionar o governo a resolver o problema agrário, de acesso à terra, consequentemente famílias inteiras passaram a morar debaixo de lonas pretas e a conviver unidas pelo laço da miséria e da esperança (MST, 2005). Nesses acampamentos, da presença de muitas crianças e a confrontação com a realidade das condições materiais de existência emergiram vários questionamentos, dentre eles:

O que estaria acontecendo em suas vidas? O que pretendem seus pais agitados, e por que fazem tantas reuniões e assembleias? Por que tantas caminhadas, tanta fome, tanta confusão? Por que uma cruz tão grande e tão esquisita no meio dos barracos escuros? O que fazer ali para passar o tempo? (MST, 2005, p. 12).

Diante de inúmeros questionamentos, mulheres mães começaram a desenvolver atividades concernentes ao processo de luta, no qual interpretavam a realidade social, rompendo com a fixação dos elementos conceituais na esfera do cotidiano (pobreza, desigualdade, fome, por exemplo) e projetando-os na trajetória histórica de classe. Entre as acampadas, havia uma professora, Maria Salete Campigotto, que passou a coordenar essas atividades.

Essa foi uma importante e significativa experiência de educação, que passou a fazer parte da vivência dos acampamentos que proliferam pelo Brasil, principalmente na década de 1990, uma vez que no processo de ocupação já havia a preocupação com a educação, como relata o assentado A: "logo que acampamos, uma das nossas primeiras preocupação foi em ter uma escola dentro do acampamento". A seguir a imagem da primeira escola no acampamento Senador Mansueto de Lavor (Fig. 5), uma casa na beira do rio. A Figura 6 mostra a escola atual que funciona na vila do Assentamento, com duas salas de aula e uma de informática, uma secretaria, uma cozinha, dois depósitos, três banheiros e um pátio.

Assim, foi nesse processo de organização que o MST passou a ter um setor especificamente de educação, construindo estratégias para reivindicar escolas dentro dos acampamentos e, simultaneamente, a construir uma proposta pedagógica do movimento. De acordo com o Dossiê organizado pelo MST (2005, p.16)

O Setor de Educação foi criado em 1988, numa reestruturação interna que dividiu o MST em setores de atividades. A inclusão de um setor específico de educação é resultado da organização de professores e pais que passam a assumir a questão educacional das crianças e dos jovens como prioridade para o Movimento. 
Figura 5: Ruínas da primeira escola do acampamento Senador Mansueto de Lavor.

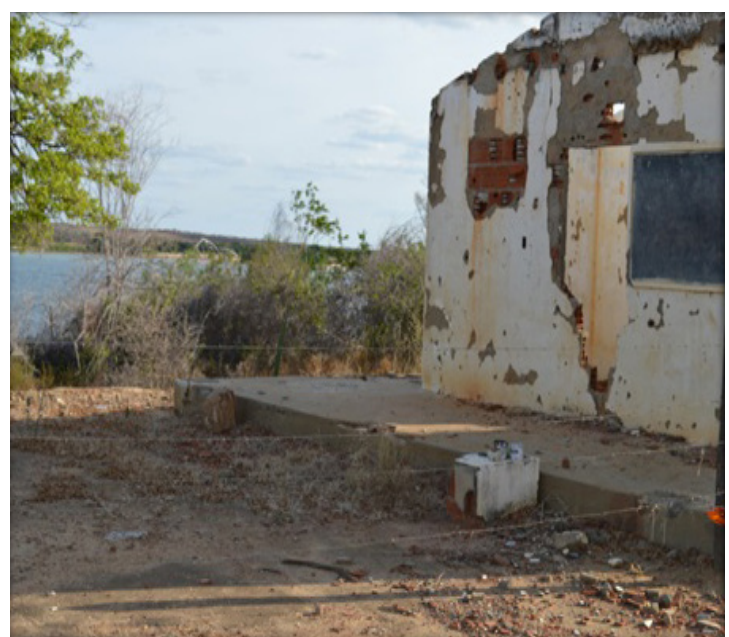

Figura 6: Escola atual do assentamento Senador Mansueto de Lavor.

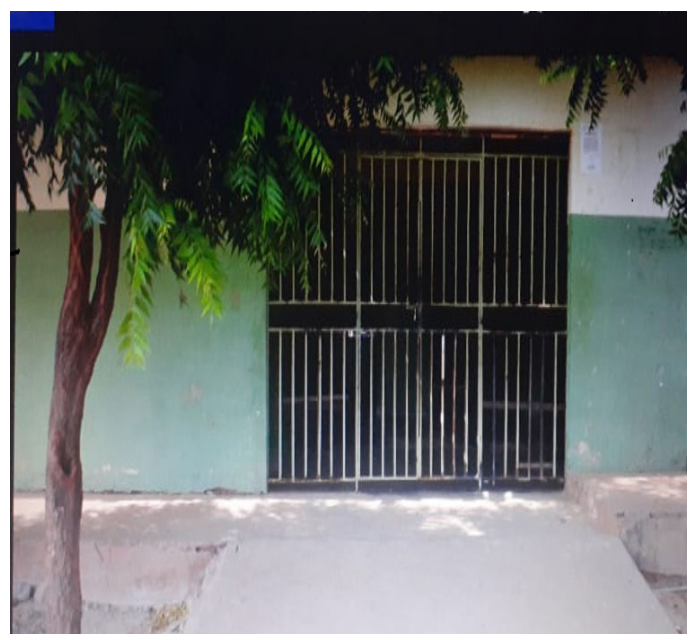

Fonte: J.C. Amorim, 2018.

Nessa direção, o Movimento de Luta por uma Educação no/do Campo realizou, em 1997, o Primeiro Encontro Nacional das Educadoras e Educadores da Reforma Agrária ENERA $^{5}$, em parceria com o Grupo de Trabalho de Apoio à Reforma Agrária da Universidade de Brasília (GT-RA/UnB), com a União das Nações Unidas para a Infância (UNICEF), do Fundo das Nações Unidas para a Ciência e Cultura (UNESCO) e da Conferência Nacional dos Bispos do Brasil (CNBB), cujo lema foi Movimento Sem Terra: com escola, terra e dignidade, que mostra a preocupação do movimento com a educação e o projeto pedagógico voltado para suas vivências, nos espaços de resistências, como o significado e sentido da produção na vida dos Sem Terra, desde criança (Fig. 7).

Figura 7: Lema do I ENERA

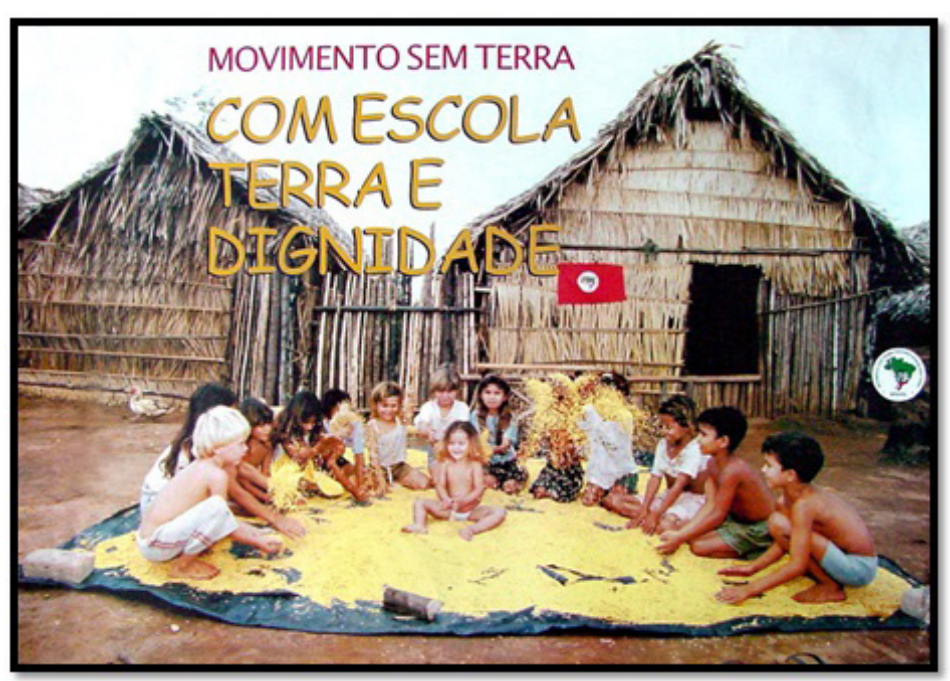

Fonte disponível em: http:/ / www.reformaagrariaemdados.org.br/biblioteca/cartaz/ movimento-sem-terra-com-escola-terra-e-dignidade.

5 O encontro reuniu mais de 700 educadores, em sua maioria professores de $1^{\circ}$ grau das escolas dos assentamentos. Teve um impacto muito grande na comunidade acadêmica e educacional por ter aglutinando pela primeira vez na história do Brasil educadores do meio rural para debater educação e reforma agrária (Fernandes \& Stédile, 2005). 
Durante o I ENERA ocorreu uma reunião com representantes das universidades, o que desencadeou a criação do Programa Nacional de Educação na Reforma Agrária $\left(\right.$ PRONERA $^{6}$ ) para enfrentar o desafio de elevar a escolarização nos assentamentos, pois os índices de alfabetização e escolarização do I Censo Nacional da Reforma Agrária, concluídos em 1996, apresentaram-se extremamente baixos (Molina, 2003). Ao final do evento, o MST foi instigado por outras entidades presentes a construir um encontro de educadores no campo, que se concretizou no ano seguinte, com a I Conferência Nacional por uma Educação Básica do Campo (MST, 2015).

O PRONERA foi oficialmente instituído em 16 de abril de 1998, por meio da Portaria n 10/1998 do então Ministério Extraordinário da Política Fundiária. O programa, que tem sido desconstruído pelo atual Governo Federal, constituiu-se na materialização de uma conquista dos movimentos sociais do campo com relação à educação, não somente por beneficiar ao longo dos anos 185.403 alunos (Fig. 8) ${ }^{7}$, mas também por amenizar as desigualdades educacionais junto aos sujeitos do campo, em particular das áreas de Reforma Agrária.

Figura 8: Número de alunos beneficiados pelo PRONERA 1998 a 2018, no Brasil.

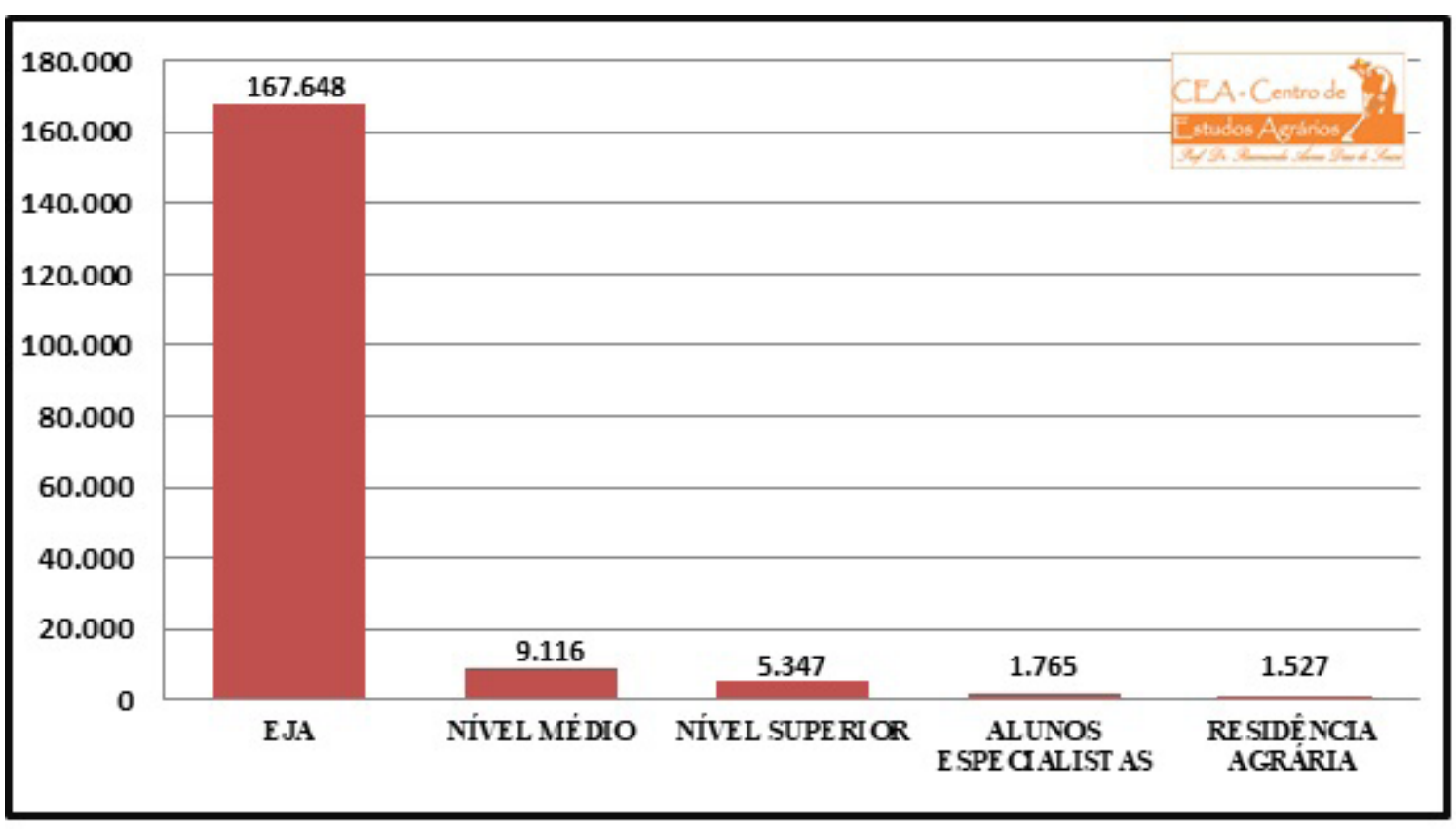

Fonte: INCRA, 2018.

De acordo com Molina e Rocha (2014), o PRONERA foi executado por meio de uma vasta articulação interinstitucional, envolvendo o Estado, as universidades e os movimentos sociais. O programa tem como objetivo geral:

6 [...] para celebrar os 10 anos do Setor de Educação do Movimento dos Trabalhadores Rurais Sem Terra (MST), e produzir um balanço dos resultados obtidos nos diferentes níveis de escolarização até então desenvolvidos (Molina \& Rocha, 2014, p. 229).

7 Os dados são desde a fundação do programa ao ano em curso, conforme o INCRA. Recuperado de http://www.incra.gov. br/educacao_pronera. 
Fortalecer a educação nas áreas de reforma agrária estimulando, propondo, criando, desenvolvendo e coordenando projetos educacionais, utilizando metodologias voltadas para a especificidade do campo, tendo em vista contribuir para a promoção do desenvolvimento sustentável (INCRA, 2018). (Grifo nosso).

Os autores, ainda, explicam que o Programa

[...]começou com alfabetização e formação de educadores assentados; depois, evoluiu para oferta dos anos finais dos ensinos fundamental e médio para os jovens e adultos que se alfabetizavam; na sequência, passou a incorporar parte das demandas da oferta de cursos técnicos profissionalizantes e superiores para os trabalhadores rurais assentados. Durante todo o processo de seu desenvolvimento, o Pronera contou com a experiência e com os princípios formativos dos Movimentos sociais e sindicais, sendo marcantes as contribuições destes para o êxito do Programa (Molina \& Rocha, 2014, p. 229).

Assim, a Educação do Campo foi incorporada na agenda de lutas de vários outros movimentos sociais camponeses e sindicais do campo, como o Movimento dos Atingidos por Barragens (MAB), o Movimento dos Pequenos Agricultores (MPA) e o Movimento das Mulheres Camponesas (MMC), e foi se consolidando e conquistando espaço, a partir de vários momentos, especialmente entre os anos de 1997 a 2018 (Fig. 9).

Figura 9: Ampliação da Educação do Campo no período de 1997-2018.

\begin{tabular}{|c|}
\hline $\begin{array}{l}1997 \text { - Primeiro Encontro Nacional das Educadoras e Educadores da } \\
\text { Reforma_Agrária. }\end{array}$ \\
\hline 1998 - Programa Nacional de Educação na Reforma Agrária. \\
\hline 1998 - I Conferência Nacional: Por uma Educação Básica do Campo. \\
\hline $\begin{array}{c}2002 \text { - Diretrizes Operacionais para a Educação Básica do Campo } \\
\text { nas Escolas do Campo. }\end{array}$ \\
\hline 2004 - II Conferencia Nacional: Por uma Educação Basıca do \\
\hline $\begin{array}{l}\text { 2008 - Diretrizes complementares, normas e principios para o } \\
\text { desenvolvimento de politicas públicas de atendimento da Educação }\end{array}$ \\
\hline Básicado Campo \\
\hline $\begin{array}{l}2010 \text { - Institucionalização da Educação do Campo e do Pronera } \\
\text { como política permanente. }\end{array}$ \\
\hline 2011 - Programa Nacional de Educação do Campo. \\
\hline $\begin{array}{c}2015 \text { - Segundo Encontro Nacional de Educadores e Educadoras da } \\
\text { Reforma_Agrária }\end{array}$ \\
\hline $\begin{array}{l}2018 \text { - Encontro Nacional } 20 \text { anos da Educação do Campo e } \\
\text { do Programa Nacional de Educacão na Reforma Agrária. }\end{array}$ \\
\hline
\end{tabular}


Nessa perspectiva, uma educação diferente daquela imposta pelo Estado passa a se concretizar na Educação no/do Campo, principalmente a partir do ano 1998, com a I Conferência Nacional Por uma Educação Básica do Campo, organizada pelo MST, CNBB, UNICEF e UNESCO, realizada em Luziânia (GO). O evento objetivou "ajudar a recolocar o rural, e a educação a que ele se vincula, na agenda política do país" (CONFERÊNCIA, 2008, p. 5). Nesse sentido, o primeiro desafio da Conferência, foi a compreensão da educação que estava sendo oferecida ao meio rural, bem como a concepção de educação presente nesse modelo. Esse conhecimento foi primordial para construir a proposta de uma Educação do(no) Campo. Conforme a Conferência (2008, p.7):

A educação do campo precisa ser uma educação específica e diferenciada, isto é, alternativa. Mas sobretudo deve ser educação no sentido mais amplo de emancipação humana, que constrói referências culturais e políticas para intervenção das pessoas e dos sujeitos sociais na realidade, visando uma humanidade mais plena e feliz.

É importante frisar que a II Conferência Nacional Por uma Educação do Campo, também realizada em Luziânia em 2004, foi significativa para sua efetivação como uma política permanente. Desse modo, Vendramini (2007) destaca a conquista, no âmbito das políticas públicas, da aprovação das Diretrizes Operacionais para a Educação Básica nas Escolas do Campo. A mesma foi instituída em 09 de abril de 2002, por meio do Parecer n. 36/2001 e da Resolução n.1/2002 do Conselho Nacional de Educação, cujo Art. $2^{\circ}$ declara:

Estas Diretrizes, com base na legislação educacional, constituem um conjunto de princípios e de procedimentos que visam adequar o projeto institucional das escolas do campo às Diretrizes Curriculares Nacionais para a Educação Infantil, o Ensino Fundamental e Médio, a Educação de Jovens e Adultos, a Educação Especial, a Educação Indígena, a Educação Profissional de Nivel Técnico e a Formação de Professores em Nível Médio na modalidade Normal (Resolução CNE/CEB 1/2002).

No ano seguinte, o Ministério da Educação designa a criação do Grupo Permanente de Trabalho de Educação do Campo e, em 2004, consolida a Secretaria de Educação Continuada, Alfabetização e Diversidade (SECAD), que se consubstanciam em conquistas advindas da mobilização dos movimentos sociais do campo. Essa Secretaria já não existe dentro da estrutura do Ministério da Educação e Cultura (MEC) e o próprio PRONERA já não tem espaço na atual conjuntura do Instituto Nacional de Colonização e Reforma Agrária (INCRA).

Assim, é preciso compreender que a Educação do Campo emerge com uma posição clara, a de lutar por terra e educação para uma vida digna, no confronto com projetos destrutivos que assolam o campo.

TERRA, TRABALHO E EDUCAÇÃO DO CAMPO - UM PROJETO PARA ALÉM DO CAPITAL

A terra é um instrumento de produção, extremamente valorizado tanto pelos trabalhadores como também pelo capitalismo. No entanto, o uso dela tem significados e interesses divergentes para o camponês e para os capitalistas. Para o primeiro 
é condição de vida, ou seja, terra de trabalho; para o segundo, é terra de negócio. Conforme Martins (1982, p.60)

Quando o capital se apropria da terra, esta se transforma em terra de negócio, em terra de exploração do trabalho alheio; quando o trabalhador se apossa da terra, ela se transforma em terra de trabalho. São regimes distintos de propriedade, tem aberto conflito um com o outro.

E o autor continua a explicar,

Quando o capitalista se apropria da terra, ele o faz com o intuito do lucro, direto ou indireto. Ou a terra serve para explorar o trabalho de quem não tem terra; ou a terra serve para ser vendida por um alto preço a quem dela precisa para trabalhar e não a tem (p. 60).

Desse modo, o campo brasileiro revela a contradição do próprio sistema capitalista, pois, ao mesmo tempo em que agronegócio se espacializa ${ }^{8}$, a luta dos camponeses por terra se amplia. Portanto, um sustenta o outro, o que significa que, na medida em que há a expansão do agronegócio, a luta por terra se expande e vice-versa. Oliveira (2001, p.18) escreve que:

Vamos encontrar no campo brasileiro, junto com o processo geral de desenvolvimento capitalista que se caracteriza pela implantação das relações de trabalho assalariado (os boias-frias, por exemplo), a presença das relações de trabalho não-capitalistas como, por exemplo, a parceria, o trabalho familiar camponês, etc.

O autor ainda explica que o desenvolvimento do capitalismo só é possível a partir das suas próprias contradições, pois é na efervescência da modernização do campo brasileiro que há a luta por terra e, ao mesmo tempo, a concentração dela por parte dos capitalistas.

Nessa perspectiva, vão se estabelecendo os conflitos por terra: de um lado, os camponeses, que lutam para permanecer na terra, de onde retiram os alimentos produzidos por meio do trabalho familiar; do outro lado, o capital, que atua na expropriação desses trabalhadores, para, em seguida, explorá-los. Conforme explica Ribeiro (2015, p.3)

[...] terra como meio de produção e, por isso mesmo, de disputa entre aqueles que nela vivem e trabalham, e o capital que a utiliza, atualmente sob a forma do agronegócio, bem como explora os trabalhadores para a produção/reprodução do lucro.

Na análise de Martins (2003, p.89), a terra, porém, que, ainda, é a base física da produção agrícola, é um instrumento não capitalista de produção,

pois ela própria não é produto do capital, como ocorre com os outros meios de produção. Ela não é, senão contabilisticamente, capital constante. Para que a agricultura

8 A produção do espaço, a organização de divisões territoriais totalmente novas do trabalho, a criação de complexos de recursos novos e mais baratos, de novas regiões como espaços dinâmicos de acumulação do capital e a penetração de formações sociais preexistentes por relações sociais e arranjos institucionais capitalistas (como regras de contrato e formas de gerenciamento da propriedade privada) proporcionam importantes maneiras de absorção de excedentes de capital e de trabalho. Essas expansões, reorganizações e reconstruções com frequência ameaçam, contudo, os valores já fixados no lugar (incorporados à terra) mas ainda não realizados (Harvey, 2004, p. 99). 
entre no circuito capitalista de produção é necessário fazer investimentos de capital, não só capital constante representado por máquinas e ferramentas, sementes e insumos, mas também em capital variável, o pagamento do trabalho de quem trabalha o salário. Ou o capital variável do salário oculto de quem trabalha em lavoura própria.

De acordo com o autor, a terra representa a irracionalidade da renda da terra capitalizada, uma irracionalidade quando convertida em equivalente de capital, quando é preciso pagar por ela. Nesse caso, a renda territorial representa uma dedução do capital disponível para fazer o empreendimento agrícola funcionar como empreendimento capitalista. Nesse sentido, o capital, na maioria das vezes, prefere não apropriar-se da terra - territorializar-se, mas apenas monopolizar a produção, o que significa que o capital assegura que o camponês ou agricultor familiar sobreviva, obrigando-o a modernizar-se, isto é, a tornar-se um capitalista pequeno ou um trabalhador, que produza para o capital.

É dentro desse conflito que se situam-se os assentamentos em estudo, o Senador Mansueto de Lavor da FETAPE e o São Francisco do MST que, mesmo tendo adquirido a terra, para garantir sua permanência necessitam recorrer ao crédito rural nos bancos, em especial no Banco do Nordeste, no qual a concessão do empréstimo impõe algumas exigências, dentre elas o cultivo de uva e manga.

Essa imposição faz parte do projeto de modernização do espaço rural, quando, em 2003, o Ministério de Desenvolvimento Agrário (MDA) ${ }^{9}$, tendo como base o conceito de desenvolvimento rural, mais especificamente do Desenvolvimento Territorial Rural (DTR), divide o país em 243 "territórios rurais"10 por região e estados. Os assentamentos estudados se enquadram no Território Sertão do São do Francisco (Fig. 10).

9 O ministério foi extinto por meio da Medida Provisória 726/2016, no governo de Michel Temer, passando a ser uma secretaria dentro do Ministério do Desenvolvimento Social e Agrário. No atual governo de Jair Bolsonaro, foi transferido para o Ministério da Agricultura, Pecuária e Abastecimento (MAPA).

10 [...] defendidos pelo Ministério do Desenvolvimento Agrário são exemplares dessa perspectiva integradora, pois agregam sujeitos diversos numa coesão forjada a partir do espaço, e não das atividades econômicas e posição social (Fabrini \& Roos, 2014, p. 62). 
Figura 10: Território do sertão do São Francisco, PE.

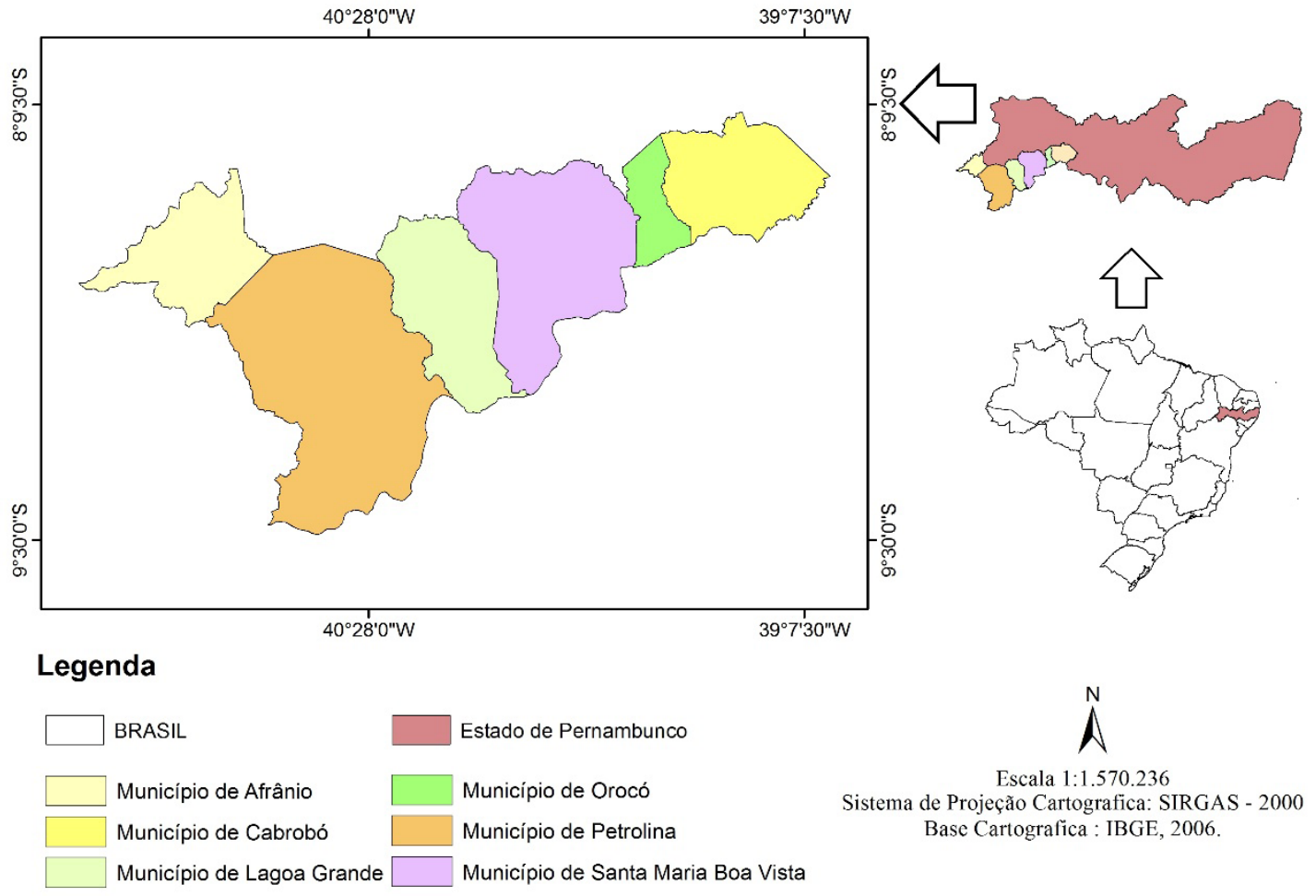

Fonte: CGMA/SDT/MDA, mar./2005. Recuperado de http://sit.mda.gov.br/download.php.

Assim, Fabrini e Roos (2014) avaliam que o DTR e o desenvolvimento local propagam a força do território para a produção de mercadorias e oportunidades em mercados dinâmicos, admitindo que o pequeno negócio se insira em distintas escalas e cadeias produtivas. Forçando os camponeses a obterem acesso aos créditos fundiários principalmente para uso de agrotóxicos, e assim elevar a produção, também levam ao endividamento e à expropriação. Os autores ainda destacam.

O caminho para obtenção de vantagens à pequena agricultura é operar como um "agronegócio familiar". A diferença entre a produção familiar e a capitalista seria apenas de escala, e o lugar do social desse "agronegócio familiar" seria garantido pela eficiência produtiva derivada da força local do território (p. 60).

Na análise de Oliveira (1998, p.8), contrário ao DTR, “território é contraditoriamente o desenvolvimento desigual, simultâneo e combinado o que quer dizer valorização, produção e reprodução". A valorização, nessa perspectiva, é evidenciada dentro dos dois assentamentos da pesquisa, quando os trabalhadores, para permanecerem na terra, são forçados a se inserir na ordem mercadológica a partir dos empréstimos bancários, cuja concessão impõe o tipo de cultivo a ser realizado, nesse caso, a uva e a manga, para assim, 
garantir a reprodução ampliada do capital. Como destaca o depoimento do assentado 2, "eu planto uva e manga no meu lote para conseguir empréstimo no banco"11.

Durante a pesquisa de campo, ficou nítida como a uva e a manga fazem parte do universo dos/as estudantes das escolas pesquisadas. A realidade imposta produz nos assentados, portanto, uma negação do modo de vida camponês, já que a produção é vista como mercadoria, valor de troca e não valor do uso, seguida de uma alienação e ao assalariamento nas grandes fazendas com objetivo de acesso aos bens de consumo. Ao solicitar-lhes para retratar o campo, eles mostram a diversidade de culturas, mas a uva e a manga ficam em evidência (Fig. 11).

A influência forte dos cultivos do agronegócio impõe à escola ocupar seu verdadeiro papel de Instituição pública dentro de assentamento de Reforma Agrária - mostrar os/as estudantes que a soberania alimentar é um caminho para se trabalhar a terra com autonomia, sem exploração da natureza e dos/das trabalhadores.

Figura 11: A realidade do campo na análise dos estudantes

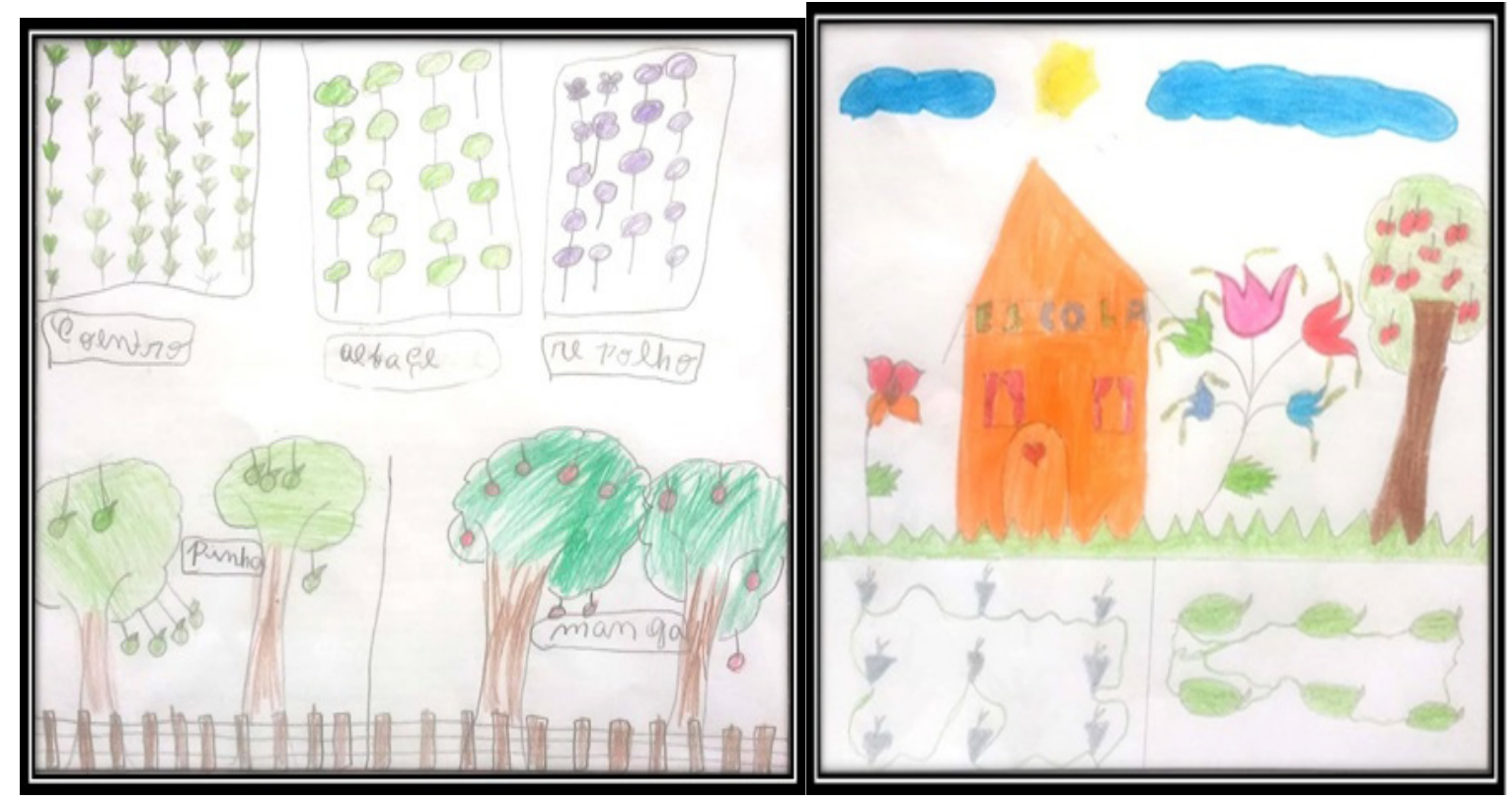

Isso é visível por parte dos/das discentes, porque, para garantir a produção de alimentos e a sua soberania, as famílias camponesas plantam uva ou manga em uma pequena área e, no restante do lote, cultivam alimentos para a família, o que significa resistência para continuar na terra, conforme depoimento do assentado 2 "eu planto outras coisas também como feijão, acerola, capim, palma, mamão, milho, temos uma horta, e criamos umas ovelhas e uma vaca"12. As imagens nas Figuras 12 e 13 mostram essa realidade dicotômica a partir da contradição criada pelo próprio capital, ou seja, de um lado a imposição e do outro, a resistência dos trabalhadores.

11 Entrevistas 2 - concedida por assentados em [fev./2018]. Entrevistador: M.A R. Silva. Petrolina, 2018.

12 Entrevistas 2 - concedida por assentados em [fev./2018]. Entrevistador: M.A.R.Silva. Petrolina, 2018. 
Figura 12: Cultivo da uva no Assentamento Senador Mansueto de Lavor, Petrolina, PE (2017).

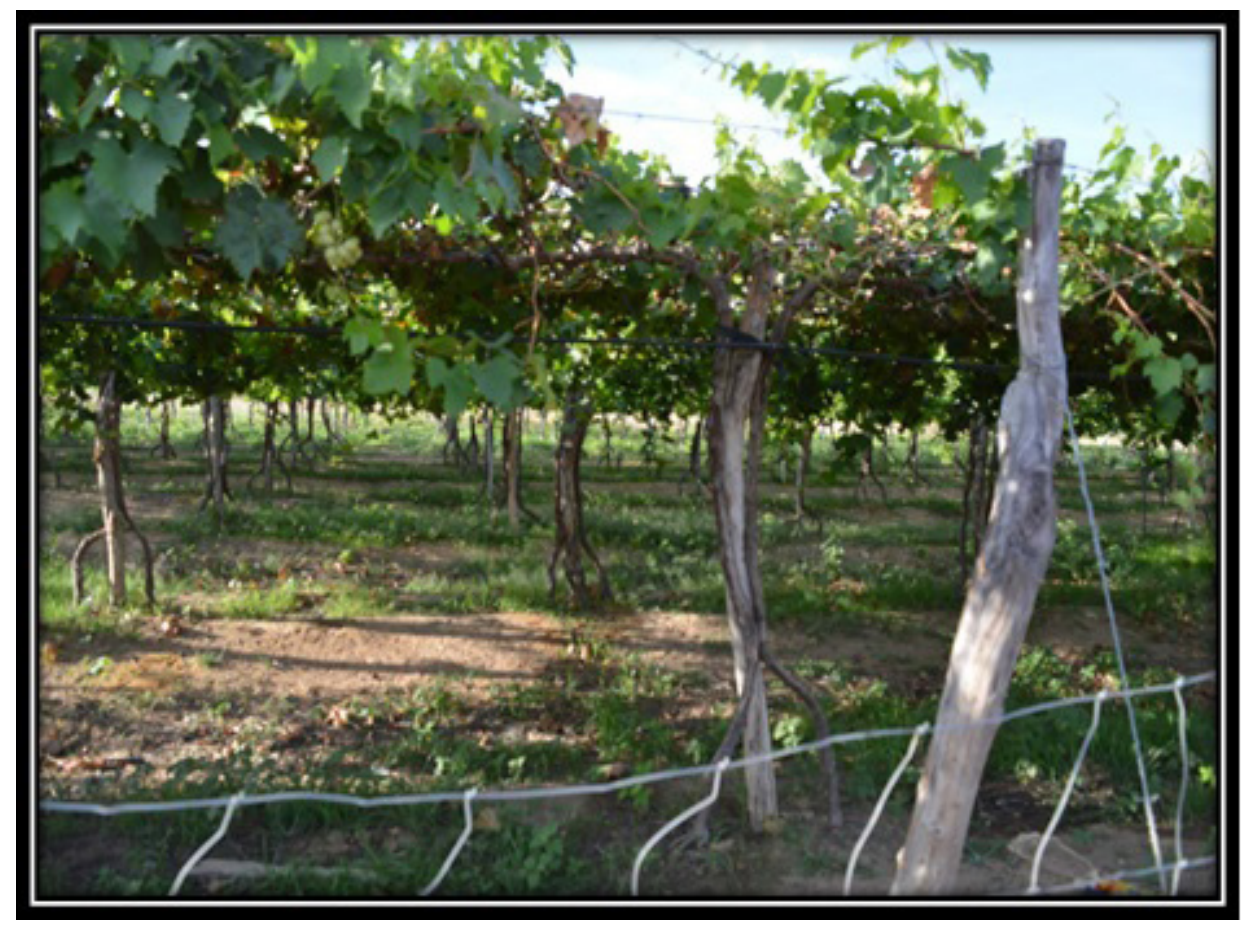

Imagem: Acervo de M.A.R. Silva, 2018.

Figura 13: Produção de autoconsumo no Assentamento Senador Mansueto de Lavor, Petrolina, PE (2017).

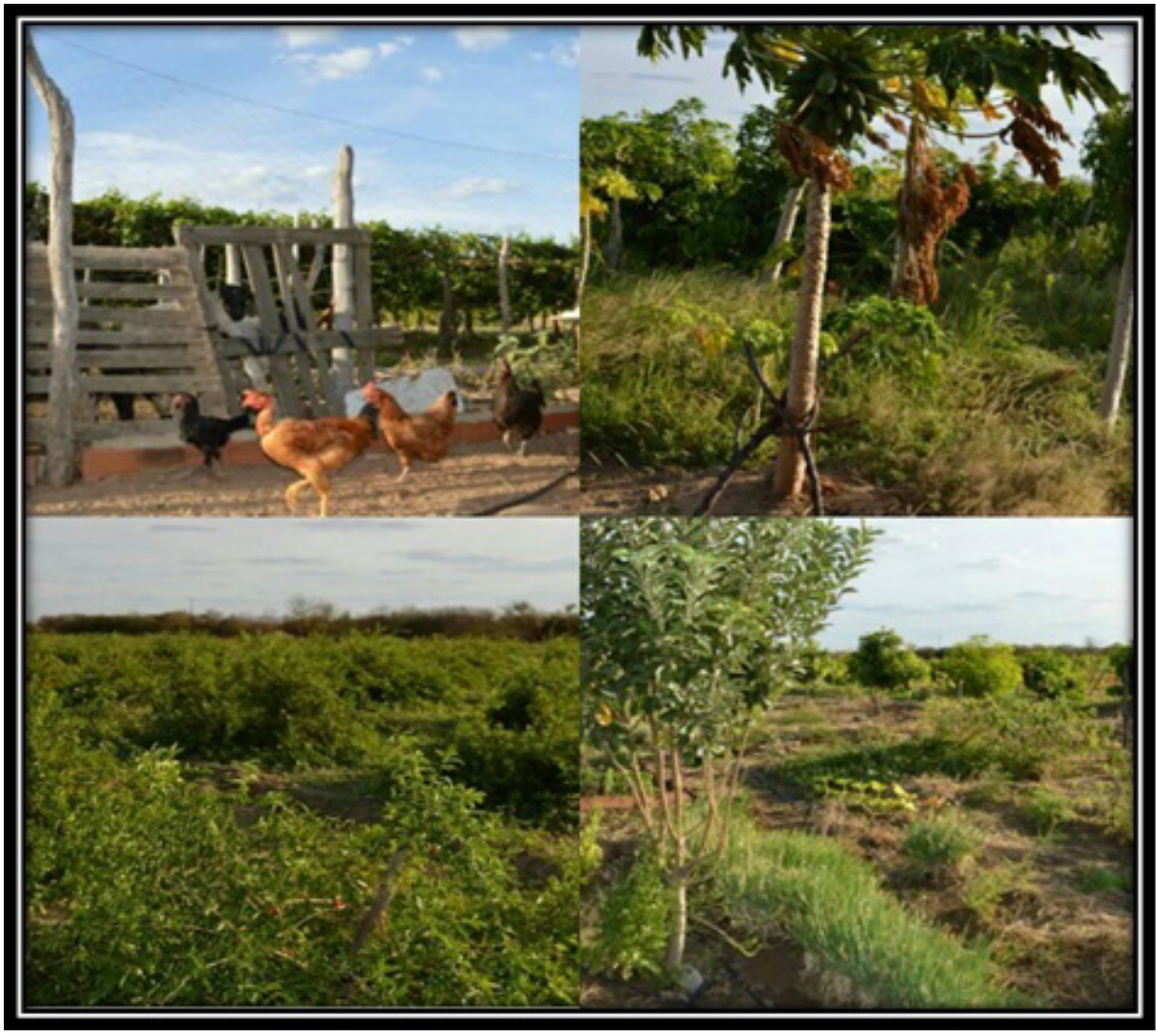

Imagem: Acervo de M.A.R. Silva, 2018. 
De acordo com Shanin (2008, p. 25), os camponeses encontram respostas nos momentos de crises a que são submetidos, ao compreender que a solução deve ser criada por eles mesmos.

As soluções encontradas para o problema de como permanecer camponês e assegurar a subsistência da família costumam ser muito flexíveis, inventivas e criativas. Camponês tem provado ser extremamente resilientes e criativos em situações de crises e não há uma forma simplista para descrever isso.

O autor, ainda, destaca que a capacidade de flexibilização, a reprodução do seu modo de vida, a diversidade de soluções encontradas para cada problema imposto pelo capital ou não, só são possíveis porque, nas particularidades camponesas, está a natureza da economia familiar ${ }^{13}$.

Seguindo a mesma linha de raciocínio, Oliveira (2007) afirma que o processo de resistência dos trabalhadores, quando cria relações de não-produção, são produto do próprio desenvolvimento contraditório do capital. Portanto, o conflito com o capital pode abrir duas frentes - uma contra o agronegócio, que se apropria da terra e nos casos, quando o camponês não é um expropriado, o capital precisa se apropriar do trabalho para, em seguida, apropriar-se dos frutos dele, isto é, da riqueza adicional que o trabalho pode criar em relação aos custos de reprodução da força de trabalho; outra, contra uma educação institucionalizada, que reproduz o sistema capitalista como um modelo eficiente.

Nesse contexto, Caldart (2012) destaca que foi no processo de luta pela terra dos movimentos sociais, especificamente no MST, que as famílias sem-terra foram as pioneiras em mobilizarem-se pelo direito de ter uma escola, dentro dos acampamentos, que fizesse a diferença em suas vidas e, nesse sentido, começaram a questionar sobre o que fazer com as crianças acampadas. Assim, a luta passa a ser também por educação, tão necessária quanto a ocupação de um latifúndio, como afirma Fernandes e Stédile (2005, p. 74), “a frente de batalha da educação é tão importante quanto a da ocupação de um latifúndio ou a de massas. A nossa luta é para derrubar três cercas: a do latifúndio, a da ignorância e a do capital".

O movimento luta por uma Educação no/do Campo que contribua para a formação política dos sujeitos, como estratégia de reprodução a partir do trabalho realizado na terra (Fig. 14). 
Figura 14: Frentes de luta do MST.

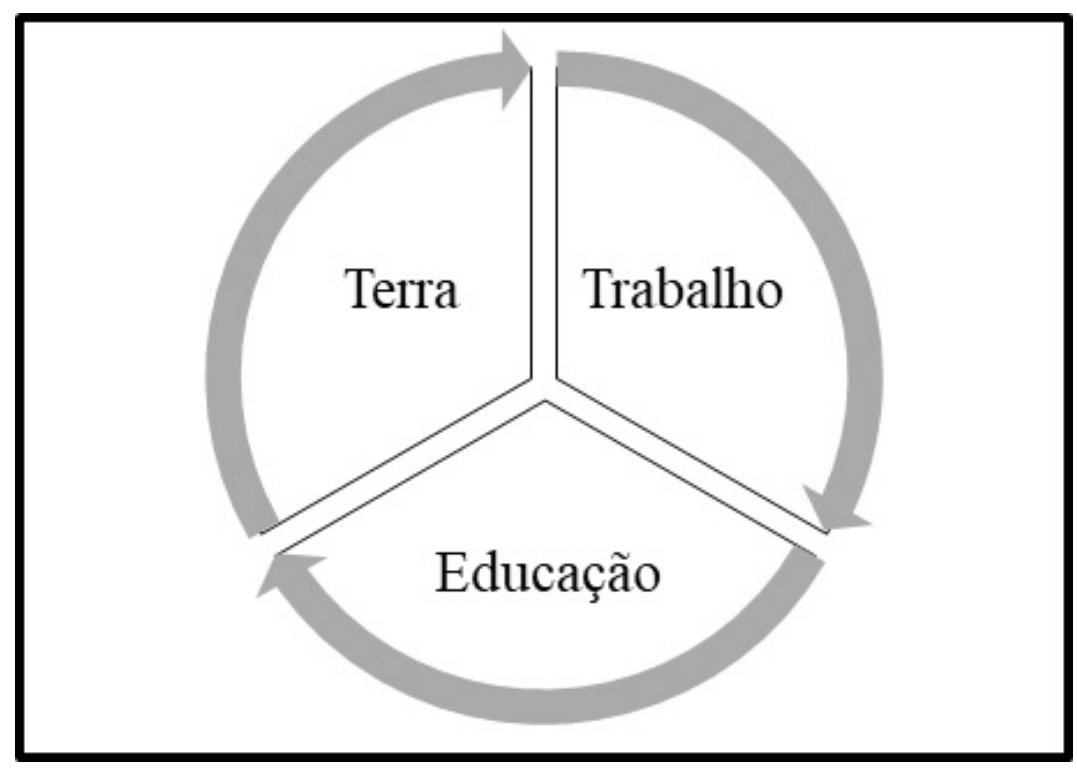

Assim, Molina e Rocha (2014, p. 6) destacam que "a Educação do Campo germina, nasce e frutifica na/da luta pela terra, pelos direitos a uma vida digna, pela relação igualitária entre homens e mulheres, pela distribuição igualitária da renda e dos bens produzidos pela sociedade de forma justa". Vendramini (2007) reforça que a Educação do Campo surge da mobilização dos trabalhadores do campo, da luta social, da organização coletiva dos trabalhadores diante do desemprego, da precarização do trabalho e da miséria.

Contudo, diante dessa realidade, abrem-se novas frentes de lutas, assim como ocorreu no nascimento do PRONERA, quando este foi resultado de uma correlação de forças favorável no âmbito da luta dos camponeses por Reforma Agrária num contexto institucional improvável, durante o primeiro mandato do Presidente Fernando Henrique Cardoso.

As condições objetivas são propicias à ocupação das beiras das estradas, dos prédios públicos dentre outros, para que a Educação do Campo ocorra como um direito. Ainda assim, ela não será para todos e todas, mesmo sendo construído dentro de uma perspectiva de classe e desde a experiência política e pedagógica dos movimentos sociais camponeses, porque no sistema do capital, há um propósito que não inclui a construção do conhecimento de forma universal. Nesse sentido, de acordo com Mészáros (2008, p. 81-82),

podemos ver que, embora o período de educação institucionalizada seja limitado sob o capitalismo a relativamente poucos anos da vida dos indivíduos, a dominação ideológica da sociedade prevalece por toda a sua vida, ainda que em muitos contextos essa dominação não tenha de assumir preferencias doutrinarias explícitas de valor. E isso torna ainda mais pernicioso o problema do domínio ideológico do capital sobre a sociedade como um todo e, por certo, ao mesmo tempo sobre seus indivíduos convenientemente isolados. 
Portanto, é necessária uma luta contínua por uma educação libertadora, que seja capaz de erradicar o capital e transformar os trabalhadores em sujeito políticos. Conforme Mészáros (2008, p. 13)

[...] a educação libertadora teria como função transformar o trabalhador em um agente político, que pensa, que age, e que usa a palavra como arma para transformar o mundo. Para ele, uma educação para além do capital deve, portanto, andar de mãos dadas com a luta por uma transformação radical do atual modelo econômico e político hegemônico.

Uma Educação do Campo e da cidade para além do capital não pode ser somente de resistência à expansão ao sistema do capital, mas, sobretudo, de destruição do próprio sistema. Do contrário, ela será acessível apenas a uma parcela da sociedade que, mesmo estando em luta, ela não atinge a todos nem mesmo em territórios específicos de Reforma Agrária. A educação para além do capital visa a uma ordem social qualitativamente diferente. "Agora não só é factual lançar-se pelo caminho que nos conduz a essa ordem como o é também necessário e urgente" (Mészáros, 2008, p. 71). Assim, no processo de organização dos movimentos sociais, continua urgente e necessário questionar o projeto de sociedade; que vá para além do capital.

\section{CONSIDERAÇÕES FINAIS}

No sistema do capital, o espaço é apropriado como condição necessária à sua reprodução. Assim, ele vai sendo condicionado de acordo com as necessidades produtivas, em cada tempo histórico.

Desse modo, para o agronegócio a educação, nesse caso a rural, é essencial para propagar os seus interesses. Nessa perspectiva, destaca-se que vários programas educacionais do agronegócio têm ocupado a educação pública nos últimos anos, como o Programa Agronegócio na Escola da Associação Brasileira do Agronegócio de Ribeirão Preto (ABAGRP), o Projeto Agroenergia e Meio Ambiente (AGORA) da União da Indústria de Cana-deAçúcar (UNICA), Projeto Escola Viva da Confederação Nacional da Agricultura (CNA), o projeto Comunidade Educativa da Bunge e o Projeto Escola no Campo, da Syngenta.

Assim, o campo da Educação Rural é o campo do agronegócio e desenvolvê-la significa acatar os financiamentos do Banco Mundial, que dita as formas como ela deve ser concebida. Desse modo, os programas para esse tipo de educação são pensados e elaborados sem os sujeitos do campo - pequenos agricultores, quilombolas, indígenas, pescadores, camponeses, assentados e reassentados, ribeirinhos, povos de florestas, caipiras, lavradores, roceiros, sem-terra, agregados, caboclos, meeiros, boias-frias. Sem sua participação, mas criado para a população do campo num espaço visto somente enquanto produção, e as pessoas como recursos.

Nas escolas dos assentamentos pesquisados, mesmo construídas em áreas de Reforma Agrária, que primavam por uma educação diferente, é aplicado o modelo estabelecido pela 
Secretaria de Educação Municipal sem considerar as especificidades do campo. Contrário a esse modelo produtivista, ou seja, o campo somente como lugar da produção de mercadorias e não como espaço de vida, é que a Educação no/do Campo pensa o campo e sua gente, seu modo de vida, de organização do trabalho e do espaço geográfico, de sua organização política e de suas identidades culturais, suas festas e seus conflitos.

Nos anos de 1997 a 2004, a espacialização da Educação do Campo por meio de diversos movimentos e organizações levou à criação de cursos novos, e a difusão do referencial teórico nas escolas gerou experiências que foram desdobradas em reflexões, estudos e pesquisas. Nesse processo, foram envolvidos outros movimentos camponeses além do MST, como o Movimento dos Pequenos Agricultores (MPA), Movimento dos Atingidos por Barragens (MAB) e Movimento das Mulheres Camponesas (MMC). A relação com instituições públicas foi ampliada por meio de parcerias com universidades federais, estaduais e comunitárias de todas as regiões. A criação de cursos de alfabetização de jovens e adultos, de cursos de nível médio e de nível superior, ao nível de graduação e pós-graduação, proporcionou a elaboração de monografias em diversas áreas do conhecimento.

Inserido nas contradições que são típicas do sistema capitalista, não se retira a grandeza do movimento por uma Educação que esteja no campo e que seja do campo, o que significa que os sujeitos estão na luta contrária à educação capitalista, onde os indivíduos são diariamente e por toda parte embebidos nos valores da sociedade enquanto mercadorias, como algo lógico e natural. Portanto é na Educação no/do Campo que se constitui uma das alternativas ao enfrentamento das desigualdades sociais.

\section{REFERÊNCIAS}

Caldart, Roseli Salete (2012). Pedagogia do movimento Sem Terra. 4.ed. São Paulo: Expressão Popular.

Conferência Nacional por uma Educação Básica do Campo. Org. CNBB, MST, UNESCO e UnB. Brasília, 27 a 31 de julho de 1998. Recuperado de http:/ / portal.mec.gov.br/secad/arquivos/pdf/educacaodocampo/ edbasicapopular.pdf

D’Agostini, Adriana (2012). A educação do campo na educação brasileira: contradições e Perspectivas. Educação, 37(3): 453-468.

Delgado, Guilherme (2005). A questão Agraria no Brasil, 1950 -2003. In Luciana Jaccoud (Org.). Questão social e políticas sociais no Brasil contemporâneo. Brasília: IPEA.

Fabrini, João Edimilson, \& Ross, Djone (2014). Conflitos Territoriais entre o campesinato e o agronegócio latifundiário. São Paulo: Outras Expressões.

Fernandes, Bernardo Mançano (2006). Os Campos da Pesquisa em Educação do Campo: espaços e territórios como categorias essenciais. In Mônica Castagna Molina. Educação do Campo e Pesquisa: questões para reflexão. (pp. 27-39). Brasília: Ministério do Desenvolvimento Agrário.

Fernandes, Bernardo Mançano (2013). Acampamento. In Roseli Salete Caldart, Isabel Brasil Pereira, Paulo Alentejano, \& Gaudêncio Frigotto (Org.). Dicionário da Educação do Campo. 2.ed. Rio de Janeiro: Escola Politécnica de Saúde Joaquim Venâncio/ Expressão Popular.

Fernandes, Bernardo Mançano; \& Stédile, João Pedro (2005). Brava Gente: a trajetória do MST e a luta pela terra no Brasil. São Paulo: Fundação Perseu Abramo. 
Fernandes, Bernardo Mançano, \& Molina, Mônica Castagna (2008). O Campo da Educação do Campo. In Sônia Meira Santos Azevedo Jesus, \& Mônica Castagna Molina (Org). Contribuições para a construção de um projeto de Educação no Campo. Brasília: Articulação Nacional Por uma Educação do Campo.

Harvey, David. O novo Imperialismo (2004). São Paulo. Edições Loyola.

Instituto Brasileiro de Geografia e Estatística. Sistema de Informações Territoriais (2018). Recuperado de http://sit.mda.gov.br/download.php.

Instituto Nacional de Colonização e Reforma Agrária. Pronera - Educação na Reforma Agrária (2018). Recuperado de http://www.incra.gov.br/educacao_pronera.

Lima, José Pinto (2005). Só a luta faz valer. Recuperado de https://mtcbrasil.org.br/quem-ta-cansado-delicenca-do-caminho

Martins, Jose de Souza (1982). Expropriação e violência: a questão política no campo. 2.ed. São Paulo: HUCITEC.

Martins, Jose de Souza (2003). A Sociedade vista do Abismo. Petrópolis: Vozes.

Mészáros, Isteván (2008). A educação para além do capital. São Paulo: Boitempo.

Molina, Mônica Castagna. Contribuições do Pronera na construção de políticas públicas de Educação do Campo e desenvolvimento sustentável (2003). Tese (Doutorado em Desenvolvimento Sustentável). Universidade de Brasília, UnB, Brasília, DF, Brasil.

Molina, Mônica Castagna, \& Rocha, Maria Isabel Antunes (2014). Educação do Campo: história, práticas e desafios no âmbito das políticas de formação de educadores - reflexões sobre o Pronera e o Procampo. Revista Reflexão e Ação, 22(2):220-253.

Movimento dos Trabalhadores Sem Terra. Setor de Educação do MST Produção (2005). Dossiê MST Escola Documentos e Estudos 1990 - 2001. Campinas: Instituto Técnico de Capacitação e Pesquisa da Reforma Agrária - ITERRA.

Oliveira, Ariovaldo Umbelino (1998). As transformações territoriais recentes no campo brasileiro. Prova de concurso para o provimento de cargo de Professor Titular. FFLCH.USP, 03/mar./1998.

Oliveira, Ariovaldo Umbelino (2001). Os elementos da Produção Camponesa. In Ariovaldo U. Oliveira. Agricultura Camponesa no Brasil. São Paulo: Contexto.

Oliveira, Ariovaldo Umbelino (2007). Modos de produção capitalista, agricultura e Reforma Agrária. São Paulo: Labur Edições.

Resolução CNE/CEB n. 1, de 3 de abril de 2002. Institui as diretrizes operacionais para a educação básica nas escolas do campo. Diário Oficial da União. Recuperado de http://pronacampo.mec.gov.br/images/ pdf/mn_resolucao_\%201_de_3_de_abril_de_2002.pdf

Ribeiro, Marlene (2015). Terra, trabalho, educação: relações que projetam desafios à educação do campo. Educação em Perspectiva, 6(2): 268-289.

Shanin. Teodor (2008). Lições Camponesas. In Eliane Tomiasi Paulino, \& João Edmilson Fabrini (Org.). Campesinato e Território em disputa. (pp.23-47). São Paulo: Expressão Popular.

Vendramini, Célia Regina (2007). Educação e Trabalho: reflexões em torno dos movimentos sociais do campo. Cad. Cedes, 27(72): 121-135.

Data de submissão: 19/abr./2019

Data de aceite: $14 /$ jul./2020 